\title{
Théologiques
}

\section{Dabru Emet}

A Contextual Analysis

\section{Michael A. Signer}

Volume 11, numéro 1-2, automne 2003

Juifs et chrétiens. L’à-venir du dialogue.

URI : https://id.erudit.org/iderudit/009531ar

DOI : https://doi.org/10.7202/009531ar

Aller au sommaire du numéro

Éditeur(s)

Faculté de théologie de l'Université de Montréal

ISSN

1188-7109 (imprimé)

1492-1413 (numérique)

Découvrir la revue

Citer cet article

Signer, M. A. (2003). Dabru Emet: A Contextual Analysis. Théologiques, 11(1-2),

187-202. https://doi.org/10.7202/009531ar d'utilisation que vous pouvez consulter en ligne.

https://apropos.erudit.org/fr/usagers/politique-dutilisation/ 


\title{
Dabru Emet
}

\section{A Contextual Analysis}

\author{
Michael A. Signer \\ Department of Theology \\ University of Notre Dame
}

\section{The Origins of the Statement}

On October 11, 2000 a notice appeared in two American newspapers that bore the headline Dabru Emet: A Jewish Statement on Christians and Christianity ${ }^{1}$. The statement began with a brief introduction and proceeded through eight headline points with a brief paragraph that elaborated the header. Over one hundred and fifty Rabbis and University professors affixed their signatures to the statement indicating that it represented their point of view.

What a strange occurrence this was. North American Jewry is very well organized. There are associations of Rabbis and of synagogues from all the major branches. In addition to these religious-based organization the Jewish community has many agencies that promote legislation that protects Jewish rights in the courts of justice and in the legislative bodies at the municipal, state and local levels of government. Two organizations of this type are very well known: American Jewish Committee and the Anti-Defamation League. Most of the statements about activities in the Christian community originate in these groups. Because all of these organizations represent large groups of people, they consider themselves competent to issue statements in the name of the Jewish people.

Dabru Emet was clearly something from a different direction. What kind of a document is it? Sociological? Theological? Who were the people who wrote the statement? Why did they do it when they did? What

1. This statement is available on the website of The Institute for Christian \& Jewish Studies, at <www.icjs.org/what/njsp/dabruemet.html>. 
motivated so many people to sign it? Who is the intended audience of Dabru Emet-Jews or Christians?

In order to explain the origins of the statement and its place in contemporary Jewish thinking about Christianity I should like to relate a true story. Four years ago I was a visiting Professor at the Hebrew University in Jerusalem. One of my colleagues had asked me to deliver a public lecture on the Catholic celebrations of the millennium.

A reporter from the Jerusalem Post newspaper asked if he might have an interview with me before the lecture took place. Since I have had experience with newspaper reporters and their difficulty with topics of interreligious dialogue, before we met I asked the reporter to please read several documents from the Catholic Church. The interview took place in a café. We sat for nearly two hours and had a very profound discussion of the papal documents and some Jewish responses to them.

When we finished our "seminar" the reporter looked at me and said, "If they can make so many serious changes in the way they approach Judaism, are we Jews not obligated to make some changes in our own attitudes about Christians?" I smiled and told him that he had reached my highest expectations. He had reached his own conclusions based on the evidence of the Christian documents that a deep change of attitude had occurred within the Christian approach to Judaism. First, Jews had a covenant with God that had never been revoked. Second, Christians had slandered the Jewish people for nearly two millennia as the deicide people. Third, many Christians have called for "repentance" toward the Jewish people.

This story serves as an introduction to why a group of Jewish scholars began to meet about eight years ago. We called ourselves "The Jewish Scholars Group on Christianity." In the first years we were sponsored by an interreligious organization in Baltimore, the Institute for ChristianJewish Studies. Our first years were dedicated to asking the question: Was there something more than pure intellectual interests for those of us who were Jewish and made Christianity a central area of our research? In other words, did our commitment to Judaism contribute to restrict our perspective in research and teaching? This question is delicate because the issue of Jewish identity is so complex and it becomes more difficult because the ethos of research at American universities has always been that the scholar should operate only on the basis of objectivity. 
It was perhaps the threat to scholarly objectivity that caused one scholar to respond so negatively when I invited her to join the group. She told me that the inquiry about the relationship between personal religious conviction and scholarly research was insulting. Why should her Jewish religion make any difference at all in her studies of the sociology of Jewish and Christian communities in the first two centuries? Reading tomb inscriptions or decoding the architecture of buildings used by either community for worship had nothing whatsoever to do with how she worshipped God or transmitted Jewish values to her children.

Despite these objections by some scholars, there were many who were quite eager to explore the possibility that there was some as yet undiscovered link between personal commitments and scholarly research. Following upon Max Weber's ethos that Wissenschaft constitutes a Beruf, a vocation, we would sit for two days and listen to colleagues from a variety of academic disciplines discuss their scholarly research. After the presentation we would probe both the historical/philosophical issues and the connection to the personal religious commitments of the individual members.

Two trends emerged within the group. There were many people for whom Christianity was an object of research. For example, if they studied rabbinic literature they would be open to comparisons of the teachings of the Rabbis with those of early Christian writers. A philosopher who studied Maimonides would be interested in how Thomas Aquinas appropriated the ideas from the Guide of the Perplexed into the Summa Theologica. Their focus was only historical and scientific. In fact, many of them had no broad theoretical framework for investigating how the Christian texts utilized in their research had any impact at all within the broader Christian tradition. They understood contemporary Christianity as a continuum of the past, especially Christian attitudes about Judaism. While they acknowledged that documents like Nostra Aetate or the Rhineland Synod of the German Lutheran Church existed, it was their opinion that a positive Christian attitude toward Judaism was confined to a small elite group of Christian scholars. For the most part these scholars considered contemporary Christianity a challenge and a threat to the health and continuity of the contemporary Jewish community.

By contrast, a smaller number of us had a different perspective. Christianity, in its history and traditions was more than simply another body of data to be mined for putting Judaism into an appropriate per- 
spective. While commitment to Judaism foreclosed our ability to understand Christianity in the same way that believers do, that very same Judaism opened up perspectives on Christianity that might not be seen as Christians did. Furthermore, we had experience not just of Christianity as a series of texts, but with a living Christian community. That Christian community did not threaten us with proselytizing efforts but presented itself as a coherent body of practices and doctrines that transformed the lives of its believers into human beings who shared a vision of the future of humankind with us as Jews. Furthermore, we recognized that a new horizon had been opened in various denominations of Christianity since the Second World War.

There were Christian theologians who were willing to begin re-thinking the two-millennia old "teaching of contempt," a body of Christian teachings that presented Jews as a danger to Christian society. Many of these Christian theologians had made these discoveries and published them at great risk to themselves and their careers. Some of them had been members of a small group of American Christian theologians who called themselves "The Christian Scholars Group." Protestant theologians such as Paul van Buren, Alice and Roy Eckhardt or Catholics such as Fr. John Pawlikowski and Sr. Mary Boys wrote about the necessary changes in Christian theology that resulted from a revised and more positive viewpoint on Judaism. Their call for a rethinking of the relationship of the Church to Judaism put them at odds with many of their colleagues and with the consensus of many people who were within their Church. Nonetheless they persisted and opened new horizons for their respective communities.

This division of opinion in the Jewish Scholars Group created a serious question for the continuing identity of the group. If the consensus of our deliberations was that Christianity was harmful to Judaism and perpetuating the cycle of anti-Jewish teachings that lead to a bad climate for the Jewish people, there was no advantage to continuing the group. There were adequate forums for people to present their research within the framework of scholarly conferences such as the American Academy of Religion or the Association for Jewish Studies. However, there was an alternative point of view that followed the following lines of thought:

a. Christianity is not a monolith. There are, in every Christian denomination, a variety of approaches to Judaism. In some cases there are Christian groups who insist on proselytizing Jews and 
who make defamatory comments about the Jewish faith. Although they do not advocate violence against the Jewish people, their belief that Jesus Christ is the exclusive path to salvation prohibits them from engaging the Jewish people as heirs to a covenant with God that has never been revoked.

b. There are Christian ecclesial bodies that have made a clear metanoia about Judaism. They have made this clear in the textbooks that transmit doctrine to their children. They have changed their Scriptural lectionaries and even re-written their liturgies where a possibility for misunderstanding exists. While Jewish organizations have honored many of the clergy who have sponsored this new relationship, there has been no Jewish response of any kind that has acknowledged the theological importance of these statements.

c. As public statements were issued by many Jewish organizations, they often revealed a distinct lack of nuance or knowledge of the serious changes that had occurred among Christians. These public statements perpetuated stereotypes and created confusion within the Jewish community. How could it be possible that Pope John Paul II would be the great friend of the Jewish community one day and its great enemy two weeks later? It appeared to several members of our group that the time had arrived for a reassessment of the relationship of Judaism to Christianity and Christians. For me in particular there was the haunting question raised by Professor Peter von der Osten Sacken of Berlin, "Who are we Christians to you?" His question demands a response within the perspective that he offered at a recent conference. These words haunt me as von der Osten-Sacken poses the central question for Jews about Christians, "Can we Jews trust you, can we trust you now?" The answer he offers is, "I think it will be possible only after three to four generations to answer this question without hesitation, because the lasting verification of a different relationship between Christians and Jews is still ahead of us."

It was Michael Wyschogrod who urged the Jewish Scholars Group to move ahead into a reflective and serious re-evaluation of an approach to Christianity at the first meeting of the group. Two years later, at an important meeting in New York City that evaluated the progress of the 
group he maintained that both communities would benefit from such a statement. Not everyone who was part of the initial Jewish Scholars Group remained involved in the smaller group that created the statement and edited the book Christianity in Jewish Terms ${ }^{2}$ that accompanied it. Some who first urged the necessity of the statement, like Wyschogrod, did not sign the published statement due to their principled disagreement with its contents. It is important to understand that Dabru Emet grew out of this long process of discussion and debate about how contemporary Jews could respond to profound changes within some parts of the Christian community.

\section{The Literary Genre of the Statement}

After the statement appeared in the newspapers and on the internet, there were some Jewish scholars who questioned its authority. They asked, quite legitimately, what gave these four scholars the authority to speak on behalf of the Jewish community? Furthermore, they asserted that a newspaper statement was not an appropriate medium to express a theological point of view. A review of how Jewish opinion is transmitted may be helpful as the background for understanding Dabru Emet.

Authorized governing bodies offered official statements by the premodern Jewish community. During the Middle Ages there were Rabbinical synods that issued Takkanot or "decrees" that were supposed to be obligatory for the Jewish community. Some of these assemblies took place in the Rhineland during the eleventh and twelfth centuries. They made significant pronouncements on areas of Jewish family law, and also on the relationship between rabbinical courts and the courts held by the German princes. During the sixteenth and seventeenth centuries the Va'ad 'Arba 'Aratzot, Council of the Four Lands, in Poland and Lithuania had both a rabbinical assembly and an assembly of notable Jewish citizens. Most of their statements focused on issues of self-government by the individual communities. Issues between Christians and Jews were restricted to areas of jurisprudence and commerce.

We find more information about the interaction between Christians and Jews in another genre of rabbinic literature, the Responsa literature

2. T. Frymer-Kensky et al., Christianity in Jewish Terms, Boulder, Colorado, Westview Press, 2000. 
written by Rabbis. Jewish communities or individual Jews would raise a question about an area of law or belief that was unclear and the Rabbi would respond. Once the Rabbi had answered, the petitioner was obliged to adhere to the pronouncement. There were many questions relating to Christians in this literature from the Middle Ages down to the present day. After the II Vatican Council both Rabbi Moshe Feinstein and Rabbi Joseph B. Soloveitchik pronounced the limitations on dialogue that would apply to Orthodox Jews.

A third literary "genre" for expressing Jewish attitudes about Christianity is the "Resolution" that is passed by the national assembly of an organization. Many groups in the Jewish community pass these resolutions at their annual meetings. The normal framework for a resolution consists of several paragraphs of introduction that indicate the "case" for the resolution and the concluding paragraph that recommends some positive or negative action by members of the group. The texts of these resolutions are often the subject of serious debate and public discussion. After passing the resolution the organization makes the text public to all its constituents and often holds a press conference where newspapers and television reporters broaden horizons of its publication. Religious and community-based institutions such as the Union of American Hebrew Congregations, Central Conference of American Rabbis, American Jewish Committee and Anti-Defamation League have passed resolutions commending various Church groups.

Dabru Emet does not coincide with any of these traditional genres. The authors of the statement were four: two Rabbis, a male theologian and a female biblical scholar and theologian. We did not represent any single denomination of American Judaism. Professor Tikva FrymerKensky is affiliated with the Conservative movement of American Judaism and teaches in the Divinity School at the University of Chicago. Professor Peter Ochs is a Professor of Jewish Philosophy in the department of Religious Studies at the University of Virginia. Rabbi Dr. David Novak is one of the leaders of the Union for Traditional Judaism and is Professor of Jewish Studies at the University of Toronto. My own affiliation is with Reform Judaism and I teach Judaism in the department of Theology at a Catholic University. Therefore, there is no denominational unity among us.

In the process of producing the statement and the book we spent many long hours of debate. Every point was reviewed and discussed 
again. Some of the points in the statement are the results of compromises where strong disagreement was replaced with language that was somewhere in between two extreme positions. We added another person to our committee, Rabbi David Sandmel, who was completing his doctoral dissertation at the University of Pennsylvania. He served as our amanuensis and facilitator-and often ended many debates by sending the four of us out of the room to meditate in solitude.

The process of writing Dabru Emet gave many of us a much more profound appreciation of the difficulty in producing such documents as We Remember: Catholic Reflections on the Shoah. It is quite clear to the discerning reader that various portions of this document were written in language that tried to harmonize divergent positions.

After two years of working on the statement we took a very bold step. We sent the draft of the document to more than three hundred Rabbis, scholars and theologians. The request was simple. We asked them to read the document and sign it without changing a word. To ask brilliant Rabbis and scholars to sign a document without inviting their ideas is the height of Chutzpah, but it made the task of publishing the statement and finishing the book simpler. To our surprise more than two hundred of them agreed to sign the statement. Those who signed were some of the most important leaders of American Jewry and included Orthodox, Conservative, Reform and Reconstructionst Jews. Within a short period of time a large group of Jews from Europe and Israel also signed the document via the Internet. Today, there are nearly three hundred signatories to Dabru Emet. Some of them have serious disagreements with one point or another in the document, but they signed despite their disagreement because they consider the overall statement to be so important.

Dabru Emet is not a definitive statement. It is the beginning of a discussion first among Jews themselves. We then hope to set the topics for an intense and profoundly serious discussion between Jews and Christians. The document itself explains our goal: "Speaking only for ourselves-an interdenominational group of Jewish scholars-we believe it is time for Jews to learn about the efforts of Christians to honor Judaism. We believe it is time for Jews to reflect on what Judaism may now say about Christianity." In other words, we invite debate and serious discussion within the Jewish community. Dabru Emet sets the framework for this discussion. 


\section{The Structure of the Statement}

The statement is an abbreviation of many hours of debate by its authors. There is a brief preface that explains the occasion its composition: to stimulate a series of reflections within the Jewish community itself. After the introductory statements there are eight paragraphs. Each paragraph begins with a brief sentence and continues with a few short sentences that are designed to provoke discussion.

Many people ask how these eight paragraphs should be read. I would make the following suggestion. The topic sentence of each paragraph such as "Jews and Christians worship the same God" can be read both as a declarative sentence with a full stop at the end and it can be read as a question. For example, "Do Jews and Christians worship the same God?" or "Can Christians respect the claim of the Jewish people upon the land of Israel?"

In putting forth this suggestion about reading the document I reveal my own disciplinary background as a medievalist. I view each of the eight brief statements as a Quaestio Disputata. Each paragraph then requires the readers to outline the arguments that affirm the statement and those that would indicate its refutation. As a result of reading and study, Jews-and Christians—can "determine" the question for themselves.

Reading the eight paragraphs in succession indicates that there is a theological structure that is at its foundation. It begins with a discussion of God and concludes with an eschatological hope that "Jews and Christians must work together for justice and peace." The authors are firmly convinced that the future of the dialogue with Christians who acknowledge the continuing covenant of the Jewish people with its God is grounded on a theistic point of view. Societal structures are surely important, but from our perspective tolerance is not a substitute for the scriptural commandments of pursuing love, justice and peace.

This theocentric foundation of the document can be discerned from the structure of the following paragraphs that focus on revelation ("seek authority from the same book"), Israel ("respect the claim of the Jewish people on the land of Israel"), ethics ("moral principles of Torah"). The statements then focus on historical and temporal questions such as the Shoah, the future of Judaism and Christianity, and the role the renewed Christianity in Jewish practice. In the final paragraph the document 
expresses a hope that Christians and Jews will live together in common work for peace and justice.

Let me point to two fundamental convictions that are at the foundation of these paragraphs. First, is that Judaism and Christianity are very different from one another and yet share very similar eschatological hopes. One should hear echoes of Martin Buber's here that Jews and Christians share a book and a hope. The foundation of our statement is the possibility to admit that the Other is different and that this very difference is the beginning of the search for common ground. In this idea our statement differs from many previous statements by Jews about Christianity that were based on the similar human condition of Jews and Christians that sought a resolution to difference in finding homogeneity.

Second is that the difference between Judaism and Christianity will be resolved only at the eschaton-the end of history, as we now know it. The implication of this second conviction is that as far as the authors of Dabru Emet understand it, God wants both Judaism and Christianity to exist until the end of time. This conviction means that efforts by Christians to proselytize Jews are the equivalent of violating the fundamental order of history. Both Christians and Jews will need to ponder deeply about the meaning of their "mission" or purpose on this earth, separately and together. However any effort by Christians to proselytize Jews would be a violation of their efforts to establish a new relationship with Judaism and the Jewish people.

\section{Some Controversies about the Statement}

This section of the paper will focus on two statements in Dabru Emet and a frequently asked question. Let me focus on the question first. Many Jews and Christians have asked the authors whether or not Dabru Emet is a statement of forgiveness for Christian transgressions against Judaism. Let me put the answer in a positive form. Dabru Emet is a response to Christian "Teshuva" or "metanoia" about Judaism. Jews can only have dialogue with those Christians who are firmly convinced that God wants the covenant made with the Jewish people to exist until the end of time. Jews can only have dialogue with those Christians who affirm the existence of the Jewish people by refraining from direct proselytizing. Jews can have dialogue with Christians who are willing to initiate serious study of their theological convictions about the nature of 
Judaism. Contemporary Jews are in no position to "forgive" Christians for what occurred in the past. We are eager to begin a serious discussion with them and build a relationship of justice, righteousness and honor for one another. Second, Dabru Emet is written to initiate discussion within the Jewish community. Very few Jews are aware of the enormous changes in Christian theology that have happened in both Catholic and Protestant churches. Most Jews learn about Christianity only from radio stations that pursue the same old themes of "His way or No way." Our hope is that they will be stimulated to learn about new attitudes within Christianity and be less afraid to enter into dialogue. That is why it was necessary for us to include the statement "A new relationship between Jews and Christians will not weaken Jewish practice." For this reason the book Christianity in Jewish Terms is a necessary part of our project.

The divergence between the newspaper announcement and the book is most clear in the paragraph that begins "Christians can respect the claim of the Jewish people upon the Land of Israel." In the newspaper announcement the entire focus is on Christian recognition that the Jewish claim to the land of Israel is based on Scripture, the common source of our revelation and authority for morality. However, the name "Israel" is a source of controversy between Jews and Christians for reasons that go beyond the boundaries of the land. At the very heart of the covenant is the name "Israel." The controversy over who is Verus Israel (the true Israel) has occupied much of the pre-modern debate in biblical hermeneutics. Who can call themselves "Israel?" Within the Jewish community there is continuing debate about who constitutes the people Israel as well as what is the nature of the state of Israel. I do believe that the essays in Christianity in Jewish Terms by Irving Greenberg and David Sandmel indicate the broad outlines of these arguments. The response by $\mathrm{R}$. Kendall Soulen is one of the most passionate essays in the entire volume. It demonstrates that the internal Jewish question of identity with Israel-land and people-and the dialogue question between Christians and Jews have a long road into the future.

There is no paragraph in the entire statement that has generated more controversy than the statement "Nazism was not a Christian phenomenon." Rabbi A. James Rudin, a well-respected author of the JewishChristian dialogue has written that his refusal to sign Dabru Emet was based on his conviction that this statement is in error. Dr. Edna Brocke in Germany has written her own forceful argument about why this state- 
ment constitutes one of many errors in Dabru Emet. Fr. John Pawlikowski, a very sympathetic Christian, has also expressed his doubts about the wisdom of such a radical sentence. The common theme among these authors is that the wording of Dabru Emet may have the effect of diminishing the Christian sense of responsibility for the Shoah. While I sincerely believe that the goal of Dabru Emet is to stimulate discussion, it is time to respond to those who think that the authors of the statement are in error when they claim "Nazism was not a Christian phenomenon."

First, I believe that a careful reading of the entire paragraph indicates precisely the opposite of what Rudin and Brocke claim. After the initial statement, the paragraph is divided into three distinct statements. The first section focuses on what we believe to be the Christian role in preparation for the Shoah: "Without the long history of Christian anti-Judaism and Christian violence against Jews, Nazi ideology could not have taken hold nor could it have been carried out." Dabru Emet does not avert its attention from the reality of Christian anti-Judaism. This topic should be the beginning of all discussions between our communities. It has been my experience that many Christians have little knowledge at all of the Christian past-even when it does not relate to Judaism. It is important for Christians to make the painful journey back into the sources of their antiJewish sentiments because it was this predisposition to think of Judaism as an outcast faith that opened the doors to Nazi Anti-Semitism. This section of the statement continues with an affirmation: "Too many Christians participated in or were sympathetic to Nazi atrocities against the Jews. Other Christians did not protest sufficiently against these atrocities." I do not think it is possible to miss the point that Dabru Emet repeats the common Jewish descriptions of the role Christianity played in shaping the background for the Shoah. Our statement also echoes many of the Christian proclamations made by EKD, national Catholic Bishops Conferences or the Vatican.

What may be new in Dabru Emet is the next section of the paragraph. "Nazism itself was not an inevitable outcome of Christianity. If the Nazi extermination of the Jews had been fully successful, it would have turned its murderous rage more directly to Christians." The experience of the four theologians who wrote the paragraph has convinced them that Christianity had and has core values that might have led it to different conclusions about Nazism. There were seeds of these actions in 
the first pronouncements of the Catholic Bishops conference that condemned Nazism. There were elements of these Christian ideas expressed in the witness of Fr. Bernhardt Lichtenberg, Fr. Alfons Delp SJ, Dietrich Bonhoeffer and Karl Barth. The fact remains that there were Christians who were murdered by the Nazi state simply because their Christian witness brought them to openly oppose Nazism. The authors of the paragraph are not making the moral equation between the Nazi policy of pursuing Jews wherever they lived in order to annihilate them and the execution of Christians who dissented in a totalitarian state. However, it is important to recognize that there were a few who did protest. Moreover, the few who did protest can serve as exemplars for contemporary Christians to follow the biblical commandment not to pursue the multitude to do evil.

The final section of this paragraph focuses on those who risked their lives to save Jews. "We recognize with gratitude those Christians who risked or sacrificed their lives to save Jews during the Nazi regime." In this sentence we move beyond those Christians who understood Nazism to be anti-Christian to praise those Christians who could look beyond the horizons of their own community. The Christian rescuers risked their lives by reaching out to Jews. That is an important theme to emphasize for both Christians and Jews. Of course one can always complain that there were too few and their efforts met with little success. However, once again, I would emphasize the pedagogic importance of holding up those who are in the minority.

The paragraph concludes with symmetry toward the first section that recognized the deep problem of Christian anti-Judaism in the past. "With that in mind we encourage the continuation of recent efforts in Christian theology to repudiate unequivocally contempt of Judaism and the Jewish people." If it was the link between Christian teaching of contempt for Judaism that made believers willing participants in Nazi ideas, it will be the work of theologians, pastors, educators and catechists who teach the new theology that will insure against another rise of Nazism. Some scholars have implicitly criticized our final sentence as too apologetic, "We applaud those Christians who reject this teaching of contempt and we do not blame them for the sins committed by their ancestors." They claim that by removing blame, we "let the Christians off the hook." In other words, our statement of praise for Christians may weaken Christian efforts to eradicate anti-Judaism and sympathy for Anti-Semitism and 
myths of Jewish economic conspiracy. I have a fundamental disagreement with this criticism. First, the reason for Jewish-Christian dialogue is not to hold anyone "on the hook" or force him or her into a defensive or apologetic position. Second, there is some disagreement among educators about how much "blame" Christians or non-religious people can absorb about the Shoah. For many years the pedagogic efforts went in this direction and the results demonstrate that it has not eliminated AntiSemitism. Perhaps the time has come to change direction and establish a discussion between Jews and Christians in which both partners are on a journey of discovery. Within the process of dialogue Christians "discover" the Anti-Judaism in their tradition for themselves, and then "choose" the responsibility for its eradication. This certainly has been my experience after ten years of teaching about the Jewish-Christian relationship in a Catholic setting.

\section{Pathways for the Future}

In the efforts to write Dabru Emet and edit Christianity in Jewish Terms, the authors recognize that they were part of a rather small group of Jews who had participated in the dialogue with Christians. It was their desire to broaden the boundaries of the discussion that moved them out of their university offices and into the area of public statements. The efforts to promote this dialogue are still in the initial stages. These are not easy times for religious groups that seek ways toward more open attitudes. There is a continuous assault on what some people call "liberal religion" that seeks dialogue instead of confrontation. In both Jewish and Christian communities there is concern that secularism is the normal practice that leads to indifference to religion. In a period of insecurity and anxiety the call for dialogue between communities is perceived as a threat.

We believe, and those who have signed our statement are convinced, that Christians and Jews have a future together that can bring blessings to the world. In order to reach the stage of serious dialogue both of our communities will have to prepare resources for our communities to study. We should study not only our common Scripture, but also our diverging interpretations of that Scripture. As we come to understand how our traditions of interpretation have shaped us, we can learn where to set appropriate boundaries for one another so that we can enjoy a mutually fruitful relationship. 
We must turn to an honest assessment of our past. That will involve the study of how our ancestors carried out their disputations with one another. We can separate the honest disagreements from the discourse of contempt for the ideas of the other. We should try to understand the dimensions of religious teachings that built the highway of mistrust and violence.

However, these painful discussions should take place within the framework of hope for the future. Without creating hope, the impulse for dialogue will diminish. No healthy community returns to a painful experience unless there is a core of hope that can be created for the future.

In the coming years, Jews and Christians should engage in a mutual search for respect, justice, and love. We should build this dialogue on a different framework than previous encounters. Both communities should face each other with the idea that we are groups of people who have spent our histories trying to live by the words, deeds and message of the Hebrew Bible. Each community has found its unique way to live out that message among themselves but not toward one another. Over the centuries, both communities have enjoyed the teaching of brilliant minds and the actions of ordinary people. We need to share these experiences and teachings with one another. We should admit from the very beginning that there are elements in each tradition that the other side cannot comprehend. We should enjoy the fact that we are different from one another. We should understand that the sweetness of agreement and the disappointment of disagreement are part of a relationship of caring for one another. There is no compromise in this encounter for there is no victory for one community or the other. There is only life together. It will be a life of "yes" and "no", of community and alienation, and of continued searching. The comfort and joy of our common and separate searches will provide the continuing motivation for our changed framework. We need not know everything that awaits us on the road ahead. The mystery of surprise will surely bring greater hope than the pessimism that growth in mutual understanding are beyond our grasp ${ }^{3}$.

3. Frymer-Kensky et al., Christianity in Jewish Terms, p. 373. 


\section{RÉSUMÉ}

Un des quatre rédacteurs de Dabru Emet explique le processus ayant conduit un groupe d'intellectuels juifs états-uniens à répondre à la question: «Que sont les chrétiens pour nous?» Il en précise la portée, les objectifs et les motivations. Il revient sur certaines controverses suscitées par la manière dont le document articule anti-judaïsmne et Shoah. Selon lui, les affirmations de Dabru Emet doivent être aussi lues sous forme interrogative pour alimenter les discussions futures.

\section{ABSTRACT}

One of the four redactors of Dabru Emet explains the process which led a group of Jews from the United States to answer the question: "For us, who are the Christians?" He describes its scope, objectives and motivations. He looks at some controversies around this document, especially those concerning the way the document articulates the link between anti-Judaism and Shoah. According to him, the affirmative statements of Dabru Emet must also be read in as questions to foster future discussions. 